\title{
浅析机电安装工程的电气施工工艺与管理
}

李玲玲

青海翔若电力工程有限公司

DOI:10.18686/bd.v2i7.1518

[摘要] 机电安装工程是建筑机械工程的重要组成部分, 其中安装调试施工工艺主要包括户外机电系统配电箱安装, 室内 低压配电箱的安装和部署以及机械设备和机电系统的安装调试等。为了保障机电工程的安全运行, 本文概述了机电安装工 程, 对机电安装工程主要的电气施工工艺及其管理措施与建议进行了探讨分析。

[关键词] 机电安装工程;电气施工工艺;管理; 措施; 建议

\section{1 机电安装工程的概述}

传统的机电安装工程是指对创造电气和相关电子系统 的学科进行综合, 当前机电安装工程已超过了这个规定范 围,将凡是与电子相关的工程都称之为机电工程,其与人们 的生产生活存在密切联系。机电安装工程包含电气工程、气 体灭火、防火卷闸工程、空调通风工程、给排水工程、消防工 程等的。而电气工程作为组成建筑工程的重要部分, 能够为 室内的照明设备、通风设备、控制系统等多个设备提供所需 的电力能源。其系统主要由变配电工程、电气动力系统工 程、备用和不间断电源安装工程、室外电气工程、电气照明 安装工程、供电干线系统工程、防雷和接地安装工程等组 成。

\section{2 机电安装工程主要的电气施工工艺分析}

机电安装工程的电气施工工艺主要有:

2.1 室外配电箱的安装

室外的配电箱的安装位置应充分考虑防雨罩, 如果是 在公共场所, 应考虑增加一个固定的箱门, 确保箱门是锁着 的,其他建筑技术与室内配电箱安装类似。同时在进行户外 配电箱安装过程中, 确保合理选择安装位置。如果户外配电 箱安装位置属于公众, 应考虑在室外配电箱添加一个相对 固定的箱门, 以确保安装配电箱的安全运行, 避免人为故障 或事故的发生。

2.2 室内低压配电箱的安装与调配

表面上涂有油漆的配电箱应保证平稳的环境, 显示分 配装置的标识应画在重要的位置, 任何电器不能安装在下 面的框中。安装部署室内低压配电箱需要确保低压配电箱 上的涂层油漆表面应光滑, 并且要符合环境保护的要求, 可 以显示低压配电装置的适用标准, 确保度数显示在最明显 的装置位置, 不允许低电压配电箱地板与任何电气安装相 连接。如果电气开关电流比较大和配电箱开关操作频繁, 为 了保证配电箱应用的安全性, 应尽量加强阻燃防爆配电箱 的使用。

\section{3 机电系统的安装调试}

机电系统安装完成后投人运行, 应严格调试。调试工作 主要包括调试准备, 启动和停止等步骤。调试前的准备工作
主要包括查看和检查设备的数据是否符合要求, 详细检查 设备的使用环境和通风口的设置, 同时合理控制布线和电 源线的分布, 测试运行电压和电流值是否满足设备运行要 求,检查所有设备是否工作正常。同时在机电系统的安装与 调试过程中, 应严格按照有关规范安装, 当电气系统安装完 成后, 为了保证运行的可靠性和稳定性后, 应进行严格的调 试, 对电气和机械设备的数据进行汇总统计和机电设备的 运行环境进行全面检查。

\section{3 机电安装工程的电气施工管理措施及其建议}

3.1 健全完善机电安装施工组织及质量管理标准。机电 安装工程电气施工管理过程中, 需要严格按照机电安装工 程的重要性和要求,通过宣传教育和严格的管理模式,确保 每名施工人员在思想上能够充分意识到机电安装工程质量 管理和控制的重要性, 确保施工人员在施工过程中能够根 据施工技术要求和施工规范进行操作。现代机电安装施工 企业, 除了快速部署应具有先进的管理理念来发展标准化 的管理系统, 还需要基于完善的技术管理加强企业机电产 品质量控制系统的建设, 应结合企业和工程建设的实际情 况,制定合理的规范化管理标准, 以使系统施工技术管理和 质量控制系统更严格和全面, 进一步提高机电安装工程的 管理系统的适用性和管理系统的操作性。此外, 根据企业发 展的需要, 进一步优化机电安装施工组织设计质量管理标 准, 规范机电安装工程质量管理标准, 帮助企业实施有效管 理, 激发专业技术人员的创新能力的建设,使更先进的技术 应用于机电工程安装和质量控制过程中。

3.2 严格配电装置施工的管理。配电装置是机电工程的 主要内容, 如果出现了问题, 设备将不能够正常工作, 降低供 电的可靠性。所以对配电设施从装置进货再到安装试用, 都 需要严格根据图纸来进行施工并实施规范性验收。配电装 置比较先进, 其生产企业一般较具规模, 拥有电业部承认的 产品使用许可证,一般不可能出现技术性的问题。

3.3 加强电缆施工的管理。电缆出现质量问题就会造成 火灾等危险事件。通常电缆沿坚井及桥架、沟道铺设。并且 电缆密度较大、数量较多,有些型号规格也十分繁杂,如果不 认真仔细严格审查, 分类归纳, 就容易导致施工紊乱, 致使运 
行期间电缆温度过高,电信号互相干扰。建筑机电的安装是 一种技术性与工艺性都十分强的工作, 如果想做好所用建 筑机电安装工作, 主要是要抓住施工期间安装设备的安装 工艺与技术条件的实际技术要求。现场的工程技术人员要 谨慎把关, 一旦遇到与规范及设计文件中不一样的情况或 施工过程中做了现场更改的内容,都要记录在案,最后再实 施系统整体的开通和调试,并建立技术管理数据和档案。

3.4 加强对影响质量的因素进行管理。机电安装工程电 气施工过程中, 对于影响质量控制的主要因素要严格控制, 施工人员必须有施工资质, 对产品的质量标准进行合理施 工,确保在施工过程中必须规范化和科学化,这些都是影响 施工质量的重要因素, 因此应根据机电安装工程的特点,制 定详细的技术和管理策略, 根据实际情况制定相应的质量 标准, 重点对电气安装工程技术管理困难问题进行解决, 控 制好质量效果的重要因素, 进而实现对安装工程质量的控 制。

\section{4 机电安装工程的电气施工管理建议}

4.1 合理设置预留点。机电安装工程电气施工的管线往 往设置在穿梁板或穿墙位置上, 因此在施工中,必须提前将 预留洞留出,且在进行预留点的设置中,必须仔细检查核对 预留洞的高度、数量以及位置, 确保数据具有准确性。另外, 可能由于施工人员未准确掌握预留洞的参数而在管线的安 装中发生桥梁扭曲的现象, 不仅对整个工程的质量造成影 响, 而且在很大程度上造成企业电力的浪费现象, 给企业带 来较大的经济损失, 进而影响企业的长远发展, 因此, 施工人 员必须提升自身素养,在工作中养成细心的良好习惯,把握 好施工中的各个细节问题,促使工程得以顺利完成。

4.2 严格材料审核。如果电气施工材料质量不合格,将 会严重影响工程施工,因此必须规范把控施工材料质量。(1) 工建企业及建设施工人员需要对材料的质量进行严格的把 关程序,选择符合国家规定、质量合格的设备及建设材料,坚 决抵制劣质材料。(2)工建企业必须对设备和材料进行二次 检测,例如、详细检测设备的名称、型号、规格及生产地址、生 产厂家、生产标准等,通过多次检测保障,确保材料质量万无 一失。最后,需加强对设备的维修,设备经过长时间的使用, 部分零件可能出现老化或损坏, 会使机器在运作过程中发 生故障,影响施工进度。因此,企业必须定期检测设备性能,
及时发现故障进行排除,以求优化工程施工效果。

4.3 规范电气施工工序。机电安装工程电气施工过程中 的施工人员需要重视工程施工质量, 首先检查设计图纸, 对 图纸中反映的问题进行分析总结, 并针对具体情况进行必 要的调整,使施工环节具有完整性,并且能够很好的保障施 工人员的安全。其次,施工方案会直接影响工程质量以及工 期,因此,施工人员须尽可能地减少施工过程受施工方案影 响的程度, 通过科学合理的施工过程的安排, 缩减工期,并不 断完善施工的平面图等, 最终达到降低成本, 工程如期完成 的目标。

4.4 明确并协调电气与土建施工的关系。通常高层建筑 工程建设都是由土建施工单位对其进行承包和管理。通过 这样的分包方式, 施工建设单位或是总承包单位对工程项 目进行承包。相关电气施工单位必须与土建施工进行良好 的配合,将工程进展、工程安全或质量等的管理工作切实融 合到施工单位的权威管理体系中, 否则可能出现由于配合 不到位导致工程质量低、施工计划被打乱的情况,进而阻碍 工程的施工进度以及相关的管理工作, 甚至影响工程的性 能。因此, 必须要协调好二者的关系, 使双方在工程建设中能 够相互协作、相互促进,共同完成目标。

\section{5 结束语}

机电安装工程质量直接关系到整个工程质量和安全, 并涉及到工程的许多后续工作。电气施工是机电安装工程 的重要内容,并直接影响到整个工程质量。对机电安装工程 电气施工的管理是保障机电工程正常运行的关键, 因此对 机电安装工程电气施工工艺与管理进行分析具有重要意 义。

\section{参考文献:}

[1]刘虎. 机电安装工程电气施工关键工序控制与管理 措施探讨[J].江西建材,2016(01):233+239.

[2]张炳洪.关键工序控制和管理在机电安装工程电气 施工中的分析[J].鬼力中国,2016(22):239.

[3]邢正.机电安装工程电气施工工艺与控制管理探微 [J].建筑工程技术与设计,2016(23):2210-2210.

[4]万文斌.刍议机电安装工程电气施工工艺与控制管 理[J].江西建材,2016(18):208+210. 